\title{
COVID 19 PNEUMONIA AND A RARE FORM OF FUNGAL PERITONITIS IN A PATIENT SURVIVOR ON PERITONEAL DIALYSIS
}

\author{
Pavlina Dzekova-Vidimliski, Vlatko Karanfilovski, Galina Severova, \\ Lada Trajceska, Irena Rambabova-Bushljetik, Igor G. Nikolov \\ University Hospital of Nephrology, Skopje, Republic of North Macedonia
}

Corresponding author: Pavlina Dzekova-Vidimliski, University Hospital of Nephrology, Skopje, R. North Macedonia, e-mail: pavlinadzekova@yahoo.com

\begin{abstract}
Peritoneal dialysis (PD) related peritonitis is usually caused by bacteria, but viruses and fungi could also affect the peritoneal membrane and cause cloudy effluent with negative bacterial cultures. We present a case of a PD patient who survived fungal peritonitis caused by Geotrichum klebahnii (March 2015) and COVID-19 pneumonia (April 2021) with peritonitis probably caused by the SARS-CoV-2 virus. The fungal peritonitis followed one episode of exit-site infection and two episodes of bacterial peritonitis treated with a wide-spectrum antibiotic. The patient's PD catheter was removed immediately upon the diagnosis of fungal peritonitis, and an antifungal treatment was continued for 3 weeks after catheter removal. The new peritoneal catheter was reinserted 8 weeks after complete resolution of peritonitis, and the patient continued treatment with PD. The patient developed severe Covid-19 pneumonia with a sudden appearance of cloudy peritoneal effluent. There was no bacterial or fungal growth on the effluent culture. A PCR test for $S A R S-C o V-2$ in peritoneal effluent was not performed. The peritoneal effluent became transparent with the resolution of the severe symptoms of Covid-19 pneumonia.
\end{abstract}

Keywords: peritonitis, peritoneal dialysis, fungi, viruses, SARS-CoV-2, pneumonia

\section{INTRODUCTION}

Peritonitis is a serious complication of peritoneal dialysis (PD) associated with significant morbidity, transient loss of ultrafiltration, possible irreversible damage of the peritoneal membrane with technique failure, and permanent transfer to hemodialysis [1, $2]$. The pathogenic bacteria were the cause of peritonitis episodes in $70 \%$ to $80 \%$ of the PD patients. At least $20 \%$ of the PD effluent culture showed no bacterial growth [2]. Viruses, including Coxsackievirus B1 and Herpes Simplex Virus, could also cause viral peritonitis in PD patients $[2,3]$. Recently, the $S A R S-C o V-2$ virus has also been detected in peritoneal ef- fluent (PF) samples in two patients on PD with Covid-19 infection [4].

Fungal peritonitis accounted for 1-12\% of all peritonitis episodes in the PD patients [5], and it was associated with high morbidity, mortality, and technique failure [6]. Candida albicans and Candida parapsilosis were the most common isolated species [5,6,7]. Rarely, some other fungi, such as Fusarium, Aspergillus, Nocardia, Penicilatum, Geotrichum candidium [7], and Aspergillus oryzae [8], have also been detected as causative agents for peritonitis. 
We present a case of a PD patient who survived fungal peritonitis caused by the unusual microorganism Geotrichum species Geotrichum klebahnii and Covid-19 pneumonia with peritonitis, probably caused by the $S A R S$ $\mathrm{CoV}-2$ virus.

\section{CASE PRESENTATION}

A 56-year-old Caucasian female patient with kidney failure of unknown origin started hemodialysis treatment in 2011. The patient was already receiving treatment for arterial hypertension and hypothyroidism. Nonadherence to the prescribed drugs was noted, and also an allergy to vancomycin, cefotaxime, and lincomycin. The patient was on maintenance hemodialysis treatment with vascular access, a central venous catheter. Thrombosis of the three created arteriovenous fistulas was the main reason for continuous ambulatory PD (CAPD) starting in 2014. The PD catheter (Tenckhoff) was implanted by open surgery. During the first year of PD treatment, the patient experienced one episode of exit-site infection caused by Methicillin-resistant coagulase-negative staphylococci (MR-CoNS), two episodes of peritonitis caused by Streptococcus viridans and Gram-indeterminate bacteria respectively, and one episode of fungal peritonitis caused by Geotrichum species - Geotrichum klebahnii. The fungal peritonitis was manifested with abdominal pain, fatigue, and cloudy effluent in March 2015. The white blood cell (WBC) count in peritoneal effluent was elevated (140 cells $/ \mu \mathrm{L}$ ) with polymorphonuclear neutrophil predominance $(80 \%)$. The intraperitoneal antibiotics were administrated immediately after effluent culture collection. The empirical regimen was ampicillin for gram-positive and amikacin for gram-negative bacteria. The blood culture was sterile and the nasal smear did not show pathogenic bacteria. The direct microscopy and Gram stain were negative. There was fungal growth on Sabouraund's dextrose agar on day 3 in the hospital. Fungus Geotrichum species - Geotrichum klebahnii was identified in the cloudy effluent, analyzed with the VITEK 2 System. Treatment of the patient with an intraperitoneal application of fluconazole with a dose of $200 \mathrm{mg}$ per day was started. The PD catheter was removed upon diagnosis of fungal peritonitis, on day 5 in the hospital. The patient was transferred to hemodi- alysis treatment with vascular access: temporary subclavian vein catheter. The intravenous treatment with fluconazole with a dose of $200 \mathrm{mg}$ after each hemodialysis session was continued for 3 weeks after the catheter removal. The patient started treatment with CAPD again in November 2015. This occurred after the second insertion of the Tenckhoff PD catheter. New episodes of PD-related peritonitis were not registered. The patient started to complain of multiple, intensely pruritic, excoriated nodules on the skin of the body. The diagnosis was prurigo nodularis, and the treatment included topical corticosteroids, phototherapy, antihistamines, and anxiolytics.

In April 2021, the patient complained of generalized weakness, nausea, diarrhea, and dry cough. A nasopharyngeal swab was obtained and a polymerase chain reaction (PCR) test for $S A R S-C o V-2$ returned positive. The patient's vital signs upon admission to the Covid hospital unit were: a body temperature of 36.7 degrees Celsius, oxygen saturation level of $98 \%$ at room air, the respiration rate of 14 breaths per minute, blood pressure of $170 / 95 \mathrm{mmHg}$, and pulse rate of 80 beats per minute (bpm). There was mild tenderness of the abdomen at the PD catheter site and pitting edema in both lower limbs of the patient. A computed tomography scan of the patient's chest showed the common Covid-19 radiological finding: ground-glass opacities in both inferior lung lobes. The treatment included intravenous administration of azithromycin and a therapeutic dose of low molecular weight heparin. Two days after hospital admission, the patient's condition worsened with the manifestation of dyspnea, tachypnea, an oxygen saturation level below $75 \%$ on a simple oxygen mask, arterial hypertension $(180 / 110 \mathrm{mmHg})$, tachycardia (160 bpm), abdominal pain, diarrhea, and the sudden appearance of cloudy peritoneal effluent. The patient was set on high flow oxygen support and intravenous administration of a high dose of corticosteroids $(240 \mathrm{mg} /$ day $)$ during 3 consecutive days with gradual dose tapering. The intraperitoneal antibiotic (amikacin) was administrated immediately after effluent culture collection. The results from laboratory analysis of patient blood and the oxygen saturation level during hospitalization in the Covid unit are presented in Table 1.

The patient remained on CAPD, assisted by the medical staff, performing four exchanges with adequate ultrafiltration. There was a decline 
Table 1. The results from laboratory analysis of patient blood and the oxygen saturation level during hospitalization in the Covid unit

\begin{tabular}{|c|c|c|c|c|c|}
\hline & Upon admission & $3^{\text {th }}$ day & $5^{\text {th }}$ day & $7^{\text {th }}$ day & $\begin{array}{c}\text { Referent } \\
\text { values }\end{array}$ \\
\hline White blood cells count (x10 $/ \mathrm{L})$ & 15.5 & 6.5 & 6.2 & 7.3 & $4.0-9.0$ \\
\hline Lymphocytes (\%) & 10.5 & 9.5 & 6.0 & 7.1 & $15-50$ \\
\hline Neutrophils (\%) & 86.2 & 86.8 & 90.6 & 90.5 & $35-80$ \\
\hline Neutrophil - Lymphocyte ratio & 8.2 & 9.1 & 15.1 & 12.7 & $1-3$ \\
\hline C-reactive protein (mg/L) & 22.7 & 76.28 & 23.2 & 12.4 & $<6$ \\
\hline Hemoglobin (g/L) & 128 & 108 & 114 & 110 & $120-180$ \\
\hline Platelet count (x10\%/L) & 213 & 120 & 146 & 138 & $150-450$ \\
\hline Albumin (g/L) & 36 & 32.8 & 32 & 30 & $35-50$ \\
\hline Lactate dehydrogenase (U/L) & 962 & 600.5 & 363 & 344 & $<248$ \\
\hline Creatine kinase (U/L) & 1112 & 246.7 & 39 & 39 & $24-173$ \\
\hline Aspartate aminotransferase & 118 & 43.1 & 18 & 27 & $10-34$ \\
\hline Alkaline phosphatase (U/L) & 205 & 149 & 116 & 121 & $36-126$ \\
\hline D-dimer (ng/ml) & 20823 & no value & 2090 & 1008 & $0-500$ \\
\hline Oxygen saturation & $98 \%$ & $75 \%$ on simple & $\begin{array}{c}95 \% \text { high flow } \\
\text { oxygen support }\end{array}$ & $\begin{array}{c}94 \% \\
\text { at room } \\
\text { air }\end{array}$ & $\begin{array}{c}95-100 \% \\
\text { at room air }\end{array}$ \\
\hline
\end{tabular}

in body weight and a consequent reduction of pitting edema on the lower limbs. There was a significant improvement in the patient's condition and vital signs, with a gradual increase of blood oxygen saturation after 24 hours of the start of treatment with a high dose of corticosteroids. The peritoneal effluent became transparent after 72 hours of started intraperitoneal application of the antibiotic. The effluent culture was sterile. The patient was discharged from the Covid unit on the $9^{\text {th }}$ hospital day with instructions to continue the isolation at home and the treatment with oral administration of antibiotic (ciprofloxacin), anticoagulant (apixaban), and a low dose of corticosteroid.

\section{DISCUSSION}

The multicenter study with 818 PD patients from four large medical institutions in Wuhan, demonstrated that the incidence rate of symptomatic SARS-CoV-2 infection in PD patients was similar to that of the general population (2.44 per 1000 person-month). [9] The patients with chronic kidney disease (CKD) who require regular hemodialysis (HD) are proven to be at a greater risk for $S A R S-C O V-2$ infection, compared to the patients on PD $[9,10]$. Ronco C. et al. described a significantly lower rate of $S A R S-C o V-2$ infection rate (1:3 patients) and a lower rate of all-cause hospitalization (2:5 patients/month) in PD patients compared to the HD patients. [10] The most commonly reported symptoms in PD patients with $S A R S-C o V-2$ infection were fever, cough, and shortness of breath, accompanied by abdominal pain, diarrhea, and myalgia. [11] Schadeva M. et al. noticed a greater incidence of gastrointestinal symptoms in PD patients compared with the general population with SARS$\mathrm{CoV}-2$ infection. Moreover, 3 of 11 patients in their study were diagnosed with culture-negative peritonitis and suspected SARS- $\mathrm{CoV}-2$ affection of the peritoneal membrane. [11]

The role of viruses as a cause of PD-related peritonitis remains unrecognized and probably underestimated because diagnostic tests for viruses are not routinely performed in PD patients suspected of peritonitis. Only several case reports with the peritonitis caused by the virus have been published. In 1999, Yakulis R. et al. reported a CAPD patient with recurrent culture-negative peritonitis, with elevated WBC count (predominantly lymphocytic) in peritoneal effluent, and histological, immunohistochemical, and electron microscopic evidence of herpes simplex peritonitis. [3] Echovirus type II, Coxsackievirus B1, and Cytomegalovirus (CMV) were also reported as causative agents of viral peritonitis in the patients undergoing CAPD. [2] The presence of $S A R S-C o V-2$ virus in the peritoneal effluent, potential transmission, and its ability to affect the peritoneal membrane remains controversial. 
The presence of the virus in peritoneal effluent in PD patients with $S A R S-C o V-2$ infection was detected with PCR testing. [4, 12, 13] However, Candellier A. et al. did not detect the presence of SARS-CoV-2 genetic material by PCR tests in serial effluents of three PD infected patients with a high viral load on nasopharyngeal swabs [14]. Similarly, Wang X. et al. noted the absence of $S A R S-C o V-2$ in 26 PD effluent samples collected after a minimum of 10 days (median, 20; range, 10-45) of the onset of Covid-19 symptoms in 11 patients with a positive nasal-swab. [15] The $S A R S-C o V-2$ virion is 60-140 nanometers and could theoretically diffuse from the blood to the peritoneal cavity. [14] On the $3^{\text {rd }}$ hospital day, our patient developed severe Covid-19 pneumonia with a sudden appearance of cloudy peritoneal effluent. There was no bacterial or fungal growth on the effluent culture. PCR testing for the $S A R S-C o V-2$ virus in peritoneal effluent and the determination of the WBC count in effluent were not performed. The peritoneal effluent became transparent with the resolution of the severe symptoms of Covid-19 pneumonia.

The patient also survived fungal peritonitis caused by an unusual microorganism: Geotrichum species - Geotrichum klebahnii. Geotrichum is a genus of fungi isolated from fruit and vegetables, air, soil, water, sewage, and dairy products. [16] Geotrichum klebahnii is a plant pathogen fungus and a component of the natural flora of the human mouth, skin, and gastrointestinal tract with possible probiotic potential. [16] Some members of the genus Geotrichum, such as Geotrichum candidium, Geotrichum clavatum, and Geotrichum capitatum could pathologically affect the lungs and the bowel, and, less commonly, the mouth, skin, and nails. Only one case of fungal peritonitis in a PD patient caused by Geotrichum candidium has been published. [7] Microbiological examination showed up positive for glossy white, moist, and slightly veined at the center culture, accompanied by a yeast identification using the VITEK ${ }^{\circledR} 2$ YST ID card. Thus it is strongly suggested that Geotrichum klebahnii was a cause for peritoneal infection in our patient. This fungal peritonitis followed one episode of exit-site infection and two episodes of bacterial peritonitis treated with a wide-spectrum antibiotic. Garcia-Agudo R. et al. summarized that previous episodes of bacterial peritonitis, recent treatment with wide-spectrum antibiotic, diabetes mellitus, immunosuppression, advanced age, prolonged time with PD treatment with a prolonged stay of the inserted peritoneal catheter were the most frequent risk factors for fungal peritonitis. [1] Antifungal prophylaxis, nystatin orally every 24 hours or fluconazole $200 \mathrm{mg}$ orally every 48 hours, should be added to initial prolonged antibiotic therapy in order to prevent secondary fungal peritonitis. [17]

The International Society of Peritoneal Dialysis (ISPD) guidelines recommended immediate catheter removal upon diagnosis of fungal peritonitis because of the refractory course and the treatment with an appropriate antifungal agent should be continued for at least 2 weeks after catheter removal. [17] A retrospective study of Chang TI et al. studied 94 episodes of fungal peritonitis in 1926 PD patients, from January 1992 to December 2008. [18] The mortality rate was significantly higher in patients with delayed catheter removal $(13 / 41,31.7 \%)$ compared to the patients with catheter removal within 24 hours $(5 / 39,12.8 \%),(p<0.01)$. Multivariate logistic regression analysis revealed that delayed catheter removal, the presence of intestinal obstruction, and higher white blood cell counts in the blood and the peritoneal effluent were independently associated with higher mortality rate in patients with fungal peritonitis. The fungi could form biofilm on medical devices (catheters) and mucosal host tissues that might serve as a reservoir for repetitive infections. [18] Miles $R$ et al. concluded that catheter removal combined with antifungal treatment resulted in the lowest mortality and risk for repeat fungal peritonitis. [19] The reinsertion of a new PD catheter should be attempted at least 6 weeks after the complete resolution of peritonitis, with successfully resumed PD program in only $12.5 \%$ of the patients. $[1,20]$ Our patient's catheter was removed immediately upon the diagnosis of fungal peritonitis, and the antifungal treatment was continued for 3 weeks after the catheter removal. The new peritoneal catheter was reinserted 8 weeks after the complete resolution of the peritonitis, with successfully resumed CAPD treatment.

\section{CONCLUSION}

The episodes of PD-related peritonitis are usually caused by bacteria, but viruses and fungi could also pathologically affect the 
peritoneal membrane and cause cloudy effluent with negative bacterial cultures. The role of the novel $S A R S-C o V-2$ virus in causing viral peritonitis, its presence, and potential for transmission with the peritoneal effluent have yet to be discovered.

\section{REFERENCES}

1. García-Agudo R, García-Martos P. Clinical and microbiological aspects of fungal peritonitis in peritoneal dialysis. Nefrologia. 2009;29(6):506517.

2. Pauwels S, De Moor B, Stas K, Magerman K, Gyssens IC, Van Ranst M, et al. Coxsackievirus $\mathrm{B} 1$ peritonitis in a patient treated with continuous ambulatory peritoneal dialysis: a case report and brief review of the literature. Clinical Microbiology and Infection. 2012;18(10):431-434.

3. Yakulis R, Babinchak TJ. Herpes simplex peritonitis: case report. Clin Infect Dis. 1999; 28:12121215.

4. Ibarra-Hernandez M, Alcantar-Vallín M, Cabrera Silva R, Sánchez-Reyes K, Alvarez-Zavala M, De Arcos-Jiménez J, et al. Detection of SARSCoV-2 in peritoneal fluid from patients with kidney disease and COVID-19: report of two cases. Research square. 2020 Sept 16; 2020/09/16 DO - 10.21203/rs.3.rs-79032/v1

5. $\mathrm{Hu} \mathrm{S}$, Tong $\mathrm{R}$, Bo $\mathrm{Y}$, Ming $\mathrm{P}$, Yang $\mathrm{H}$. Fungal peritonitis in peritoneal dialysis: 5-year review from a North China center. Infection. 2019 Feb;47(1):35-43.

6. Auricchio S, Enrica Giovenzana M, Pozzi M, Galassi A, Santorelli G, Dozio B, Scanziani R. Fungal peritonitis in peritoneal dialysis: a 34year single centre evaluation. Clinical Kidney Journal. 2018;11(6):874-880.

7. Garza J, Miranda R, Garza A, Texis A, Díaz E, Juárez U. Peritonitis due to Geotrichum candidum in Continuous Ambulatory Peritoneal Dialysis. Case Reports in Clinical Medicin. 2018;7:232-240.

8. Schwetz I, Horina J, Buzina W, Roob J, Olschewski H, Krause R. Aspergillus oryzae Peritonitis in CAPD: Case Report and Review of the Literature. American Journal of Kidney Diseases. 2007;49(5): 701-704.

9. Jiang HJ, Tang H, Xiong F, Chen WL, Tian JB, Sun J, et al. COVID-19 in Peritoneal Dialy- sis Patients. Clin J Am Soc Nephrol. 2020 Dec 31;16(1):121-123.

10. Ronco C, Manani SM, Giuliani A, Tantillo I, Reis $\mathrm{T}$, Brown EA. Remote patient management of peritoneal dialysis during COVID-19 pandemic. Perit Dial Int. 2020; 40: 363-367.

11. Sachdeva M, Uppal NN, Hirsch JS, Ng JH, Malieckal D, Fishbane S, et al. COVID-19 in Hospitalized Patients on Chronic Peritoneal Dialysis: A Case Series. Am J Nephrol. 2020;51(8):669-674.

12. Coccolini F, Tartaglia YD, Puglisi A, Giordano $C$, Pistello M, Marianna Lodato $M$, et al. SARS-CoV-2 Is Present in Peritoneal Fluid in COVID-19 Patients. Annals of Surgery. 2020 Sept;272(3):240-242.

13. Vischini G, D'Alonzo S, Grandaliano G, D'Ascenzo FM. SARS-CoV-2 in the peritoneal waste in a patient treated with peritoneal dialysis. Kidney Int. 2020 Jul;98(1):237-238.

14. Candellier A, Scohy A, Gillet N, Muylkens B, Morelle J, Belkhir L, et al. Absence of SARSCoV-2 in the effluent of peritoneal dialysis patients. Perit Dial Int. 2020 Sept;40(5):499-503.

15. Wang $X$, Patel A, Tisdale L, Haq Z, Ye X, Lasky R, et al. SARS-CoV-2 in Spent Dialysate from Chronic Peritoneal Dialysis Patients with COVID-19. Kidney360. 2021 Jan;2(1)86-89.

16. Vohra S, Vohra A. Probiotic attributes of a yeastlike fungus, Geotrichum klebahnii. African Journal of Microbiology Research. 2014;8:20372043.

17. Li PK, Szeto CC, Piraino B, de Arteaga J, Fan $\mathrm{S}$, Figueiredo AE, et al. ISPD Peritonitis Recommendations: 2016 Update on Prevention and Treatment. Perit Dial Int. 2016 Sep 10;36(5):481 508.

18. Chang TI, Kim HW, Park JT, Lee DH, Lee JH, Yoo $\mathrm{TH}$, et al. Early catheter removal improves patient survival in peritoneal dialysis patients with fungal peritonitis: results of ninety-four episodes of fungal peritonitis at a single center. Perit Dial Int. 2011 Jan-Feb;31(1):60-6.

19. Miles R, Hawley CM, McDonald SP, Brown FG, Rosman JB, Wiggins KJ, et al. Predictors and outcomes of fungal peritonitis in peritoneal dialysis patients. Kidney Int. 2009 Sep;76(6):622628.

20. Lopes K, Rocha A, Rodrigues A, Carvalho MJ, Cabrita A. Long-term peritoneal dialysis experience: quality control supports the use of fluconazole to prevent fungal peritonitis. Int J Artif Organs. 2013 Jul;36(7):484-488. 


\title{
Резиме
}

ПНЕВМОНИЈА ПРИ ИНФЕКЦИЈА СО САРС-КОВ-2 И РЕТКА ФОРМА НА ГАБИЧЕН ПЕРИТОНИТ КАЈ ПАЦИЕНТ НА ПЕРИТОНЕАЛНА ДИЈАЛИЗА

\author{
Павлина Џекова-Видимлиски, Влатко Каранфиловски, \\ Галина Северова, Лада Трајческа, Ирена Рамбабова-Бушљетиќ, Игор Г. Николов \\ Универзитетска клиника за нефрологија, Скопје, РС Македонија
}

Акутниот перитонит асоциран со перитонеалната дијализа (ПД) вообичаено е предизвикан од бактерии, но вирусите и габите исто така може да ја афектираат перитонеалната мембрана и да причинат заматена дијализатна течност со негативни бактериски култури. Презентираме случај на пациентка на ПД, која преживеа епизода на габичен перитонит предизвикан од Geotrichum klebahnii (март 2015 година) и тешка пневмонија од САРС-КоВ-2 (април 2021 година) со асоциран перитонит, веројатно предизвикан од вирусот. Габичниот перитонит кај пациентката следуваше по една епизода на инфекција на излезното место на катетерот за ПД и две епизоди на бактериски перитонит, третирани со антибиотици со широк спектар на дејство. Катетерот за ПД кај пациентката беше отстранет веднаш по поставувањето на дијагнозата за габичен перитонит и со антимикотичен третман во текот на 21 ден се постигна резолуција на инфекцијата. Нов катетер за ПД беше повторно поставен кај пациентката по осум недели од излекувањето на габичниот перитонит и пациентот го продолжи третманот со ПД. Во април 2021 година кај истата пациентка беше дијагностицирана тешка пневмонија од САРС-КоВ-2 со заматување на перитонеалниот лават, временски асоцирано со пад на сатурацијата со кислород и влошување на пневмоничниот наод. Микробиолошките култури од заматениот лават не покажаа раст на патогени бактерии и габи. Тестирањето за присуство на вирусот САРС-КоВ-2 во примерок од лаватот не беше направено. Сепак, се забележа постепено избистрување на перитонеалниот лават напоредно со третманот и подобрување на симтомите асоцирани со пневмонијата од САРС-КоВ-2.

Клучни зборови: перитонит, перитонеална дијализа, габи, вируси, САРС КоВ-2, пневмонија 